\title{
The Impact of the Incubator on the Internationalization of Firms
}

\author{
Raquel Engelman', Aurora Carneiro Zen², Edi Madalena Fracasso ${ }^{3}$
}

\begin{abstract}
This paper aims to examine how technology incubators contribute to the internationalization of incubated Brazilian companies. To do so, was developed a framework that, in addition to supporting research, can be used to provide a basis for studies of internationalization in small technology-based companies and incubators and to assist their managers. By comparing the factors identified as influencing internationalization and the actions and services provided by the technology incubators, an integrated model with four constructs (entrepreneurs; organizational characteristics; network; foreign market) was built. The results demonstrate that incubation positively affects the internationalization of companies and indicate the actions and services that contribute towards the internationalization, as also reveals aspects that could be improved.
\end{abstract}

Keywords: internationalization; technology incubators; incubated companies.

\footnotetext{
'Institute of Applied Social Sciences, Feevale University. ERS-239, 2755 - Novo Hamburgo/RS - Brazil - zip code 93352-000. Phone +55.5I.84036626. E-mail: raqueleng@feevale.br (corresponding author).

2,3 Graduate Program of Management, Federal University of Rio Grande do Sul. Rua Washington Luis 855, Porto Alegre/RS - Brazil
} 


\section{Introduction}

In recent decades, the global economic scenario has undergone major transformations due to several factors such as globalization, the emergence of new markets, technological and information advances, and a growing demand for novelty, leading to strong socio-economic development and generating changes at various levels in organizations. At the same time, uncertainty and the pace of change directly affected the markets, intensifying competition, which has contributed to the increase of organizational challenges, and creating the need for companies to reassess their strategies. The literature on international business has highlighted that international expansion represents an opportunity for growth and to create value for the company. Enterprises that enter international markets generally increase their technological and market expertise, improve their performance and often become more innovative and therefore also stronger competitors in their national markets.

However, small businesses, especially startups, may need a great deal of assistance in the process of consolidation and to achieve internationalization. Rather than let the entrepreneurial effort evolve from a natural market dynamic, which may require a long time, it is possible to create an environment that fosters the development of projects and increases the chances of success. In the Brazilian experience, technology incubators represent the possibility of creating this favorable environment.

Incubators are shared spaces that provide startups with space and organizational resources, monitoring and business assistance. The new businesses are accompanied during the incubation period and helped through their introduction to and consolidation in the market, enhancing their chances of turning into successful enterprises. In a business incubator the companies also have the opportunity to share experiences with other incubated firms and to form network relationships.
After a period in which the incubators have become consolidated, several studies have begun to look into their contributions and limitations, in order to bring about improvements and provide better outcomes for the businesses and society, since many of these incubators use for public resources. In addition, the incubated companies enjoy a privileged environment in relation to other new businesses, and as such should provide innovations and higher performance. One way of achieving these goals may be by finding foreign partners and new markets. Therefore, the globalization of markets suggests that technology incubators should provide incubated businesses services and actions, besides those generally available, designed to promote their internationalization.

Considering the increased international competitiveness, technology incubators, besides supporting the initial phase of the business and the development innovative activities, have begun to offer services and actions designed to contribute to the internationalization of the incubated enterprises. Therefore, the purpose of this study was to examine how technology incubators contribute to the internationalization of incubated Brazilian companies. To do so, we conducted a survey with incubated companies in Brazil.

The extensive literature on incubators has dealt with the incubation process, the quality of services or the regional impact of these organizations, but little attention has been given to the needs of the incubated companies that face new competitive challenges such as international competition. This study aims to fill a gap in relation to knowledge regarding the contributions of incubators in the internationalization of technology-based companies.

\section{Internationalization and Incubated Companies}

This section presents the major theories and models of internationalization of companies, with emphasis on the behavioral approach, whereas the incubated companies are mostly small technology companies with limited resources. Also discussed are the main services and actions of incubators aimed at internationalization, giving rise to the framework of analysis.

The theories that deal with the internationalization of firms according to their analytical perspective can be classified into two main groups. First, the group of approaches towards internationalization is based on economic criteria aiming at the maximization of profit. Decisions of large multinational companies are supposed to be guided by these approaches (Andersen and Buvik, 2002). The second group, the behavioral approaches, consider that the

ISSN: 07I 8-2724. (http://www.jotmi.org) 
internationalization process depends on knowledge and attitudes, perceptions and behavior of decision makers in the pursuit of risk reduction (Andersen and Buvik, 2002). This perspective is mainly represented by the stages models such as the Uppsala Model (Johanson and Vahlne, 1977) and the I-Models (Bilkey and Tesar, 1977; Cavusgil, 1980; Czinkota, 1982; Reid, 198I), the Network Model (Coviello and Munro, 1997; Johanson and Vahlne, 2003), the Born Globals view and the International Entrepreneurship (Madsen and Servais 1997, Oviatt and McDougall, 1994; Rennie, 1993).

As the focus of this work is the contribution that technologybased incubators are make towards the internationalization of their incubated companies, which are mostly micro and small technology companies with limited resources, the behavioral approach will be prioritized.

According to Hilal and Hemais (2003), in the mid 1970's, several papers reporting how the Swedish companies internationalized their business were published by the University of Uppsala and came to be a part of the so called Uppsala Model of internationalization. With the new line of thinking the study of international business was no longer be considered a purely economic phenomena, but came to be also analyzed from the perspective of the Theory of Organizational Behavior. Thus, the international firm came to be defined as an organization characterized by cumulative learning processes with a complex structure of resources, skills and influences (Hilal and Hemais, 2003). The Uppsala Model (U-Model) focuses on the development of the individual firm, and is mainly concerned with the acquisition, integration and use of knowledge about foreign markets and operations and the heightened commitment to these markets through sequential stages. Because knowledge is constructed incrementally, internationalization would be a gradual process, the main barriers being lack of knowledge about foreign markets and psychic distance (Johanson and Vahlne, 1977; 2003).

The internationalization models related to innovation, known as I-Models, are also based on the behavioral approach and explain internationalization in terms of a sequence of learning stages. However, these models consider the decision to internationalize as an innovation for the firm. The main studies related to this approach are those of Bilkey and Tesar (1977), Cavusgil (1980), Czinkota (1982) and Reid (198I). A common feature in these models is the importance attributed to the size of the firm, highlighting the peculiarities of small businesses.
With the development of new internationalization processes, the theory of sequential stages was no longer sufficient to explain the reality in which firms found themselves. The Nordic School of International Affairs, which succeeded the Uppsala School, addressed the main controversies and expanded the original research, giving rise to the Network Approach, in which markets themselves are seen as business networks (Hilal and Hemais, 2003). A considerable number of the studies concerning small businesses and internationalization indicated great relevance to the networks and their internationalization process (Jones, 1999; Rocha et al., 2005; Sharma and Blomstermo, 2003). The relationship networks abroad supply the new enterprises with knowledge about markets and customers, and provide the legitimacy and references necessary for their growth, reducing the risk involved in international transactions (Coviello and Munro, 1997; Oviatt and McDougall, 1994).

In contrast to the studies involving large, mature companies, and those about small businesses in a gradual process of internationalization, the new international ventures, 'global start-ups', or 'born globals', are characterized by being international from the start (Oviatt and McDougall, 1994; McDougall, Oviatt and Shrader, 2003; Madsen and Servais, 1997). The first specific study on the subject was by McDougall (1989), but the term 'born globals' was coined by Rennie in 1993 in a study conducted in Australia, to designate new ventures with a global vocation from the outset (Rocha et al., 2005).

The International Entrepreneurship approach is a combination of innovation-oriented behavior, pro-activity and calculated risks that go beyond national boundaries and seek to create value for organizations (Styles and Seymour, 2006). This approach emphasizes the role of individuals and the search for opportunities in an attempt to explain the international expansion of new businesses through the analysis of how entrepreneurs recognize and exploit these opportunities (Coviello and Munro, 1997; Andersson, 2000). Size remains an important source of advantage for some multinational enterprises. However, economic, technological and social changes have required additional resources. International advantage has come to increasingly depend on the possession of unique resources, which allows organizations such as the new ventures to enter the international arena (Madsen and Servais; Oviatt and McDougall, 1994). Several studies have argued that for the internationalization of enterprises to be better understood, it is needed an integrated framework of various models and theories (Coviello and Munro, 1997; Johnson, 2004). As can be seen in this chapter, various factors affect the internationalization of enterprises, especially micro and small technology-based companies. 


\section{Incubators' Actions and Services oriented towards Internationalization}

A large number of small businesses, which begin their activities in the international market, after some time, come to find they have great opportunities for growth in other countries through export activities. The fact that the company is exposed to challenging cultures, more aggressive competitors, more complex operations and a need for innovation, flexibility and agility, it is assumed that the company become more competitive, including in its domestic operations, thus enhancing its results.

Proactively seeking business opportunities abroad is one way of supporting enterprises. Within this context, there is the installation of international incubators, such as the American International Business Incubator in Silicon Valley, California and the Austin Technology Incubator in Texas.

The InfoDev Incubation Support Center (Idisc, 2008) has stressed the importance of international initiatives in incubators. According to the institution, in order to expand exports, many incubators, such as The Khem Incubator (Uruguay) and the Innpulsar and Rioinnova Incubators (Ecuador) are making use of the International Trade Centre (ITC), which helps incubators contribute towards the internationalization of the incubated companies. The European Commission (2002) and Idisc (2008) are providing opportunities for international networking to facilitate access to foreign markets for companies in more than 80 business parks and incubators in the EU, China, India, United States, South America and Turkey. The Casablanca Technopark Incubation Center (Morocco) is also developing a service for companies to access the international market. Another Idisc initiative, coordinated by Anprotec in partnership with the International Business Incubator, is form a center of excellence and reference for the enterprise incubation sector worldwide, integrating international partners and disseminating information on policies and best practices for technology-based incubators (Idisc, 2008).

In a study on the management of technology incubators, which compared incubators in the United States, France and Brazil, Stainsack (2003) found that the foreign incubators offered internationalization-related activities and services such as international relations, export promotion, international searches for incubated companies, and advice on industrial property and foreign trade. In a survey of 107 incubators in Europe, Aerts, Matthyssens and Vandenbempt (2007) found that, among other services, $52 \%$ provided assistance with exports or the search for partners abroad.
According to the Eastern European and Central Asian Business Incubators Network (Ecabit, 2008), a network of business incubators and technology parks in Eastern Europe and Central Asia, several incubators around the world provide some type of service designed specifically to help the internationalization of companies. In a study of incubators in 10 countries (Armenia, Belarus, Bulgaria, Kazakhstan, Kyrgyzstan, Romania, Russia, Turkey, Ukraine and Uzbekistan) on the motivations for participating in business incubator networks, international cooperation strategies and experience transfer knowledge among incubators, it was found that most offered international business contacts through networks and international partners of the incubators, facilitating participation in international programs and networks and information services. Furthermore, some provide services related to the international transfer of technology, consulting as well as import and export services (Ecabit, 2008).

In Brazil, both the actions and studies related to the internationalization of incubated companies are still incipient. In 1993, the CNPq initiated the creation of the National Export Software Program (Softex) with emphasis on the external market. Softex participates in the generation of new enterprises, export training, resources for investment in export, support for participation in national and international events, market research and marketing support abroad (Softex, 2008).

In an analysis of secondary data from Brazilian studies on incubators until 2004, which examined the success factors for international entrepreneurship of upcoming companies provided by technology incubators, Baeta,Borges andTremblay (2006) found that the global vision of the entrepreneurs from the beginning of the project and the close link between products and services is a consistent feature. In contrast, the international market experience of the company's management team, the international business relationships network of the incubator, range of technologies or markets and control over any single intangible asset by the company were more rarely found. The main difficulty identified was access to venture financing, which would undermine the international integration (Baeta, Borges and Tremblay, 2006).

In a survey conducted in 2003, Anprotec found that $69 \%$ of the incubators offered support in relation to intellectual property and $41 \%$ offered support for exports. More recently, in December 2008, Apex Brazil and Anprotec established an agreement to boost the exports of Information Technology and Communication companies within incubators and Science Parks. The focus is on leveraging internationalization strategies to attract productive foreign investment into the sector and promote the exchange of technology-oriented businesses (Apex Brazil, 2009). 


\section{The Influence of Incubators towards the Internationalization of Incubated Companies}

A model has been developed that, in addition to supporting the present research, could, it is hoped, provide a basis for studies of internationalization in small technology-based companies and incubators. The model was developed based on the literature from the two areas of interest dealt with in this study. On the one hand, using the literature available on the internationalization of companies, a survey was made of the factors that influence the internationalization of enterprises, especially micro and small technology-based companies, and on other, the aspects of the incubation process of technology-based enterprises were studied, as well as the actions and services provided by incubators.

The factors influencing the internationalization of micro and small technology-based companies were first identified and then by congruence or complementarity, they were grouped under the aegis of the constructs representing the different theories of internationalization found in the literature.
Based on the literature review conducted in the second session, a summary was made of the main activities and services provided by incubators to incubated companies. By comparing the factors identified as influencing internationalization and the actions and services provided by the technology incubators, an integrated model was built for evaluating the contributions of the incubators towards the internationalization of the incubated micro and small technology-based companies, which are summarized in Figure 1 .

The construct 'Entrepreneurs' includes the characteristics and experiences of entrepreneurs in the incubated companies in relation to the external market. 'Organizational Characteristics' refers to the internal capabilities of the incubated companies that are important to the internationalization of the enterprise. The 'Network' construct includes both national and international networks of business relationships of the companies and of the incubator, which influence the internationalization of incubated companies. The 'Foreign Market' construct comprises the features of the global environment including global integration of the sector and the specific features of each foreign market targeted for the internationalization of the company. The Figure 2 presents the operationalization of each construct. We argue that the perception of these constructs will be different according to: international operations (international or domestic), internationalization program of incubator and international experience of managers.

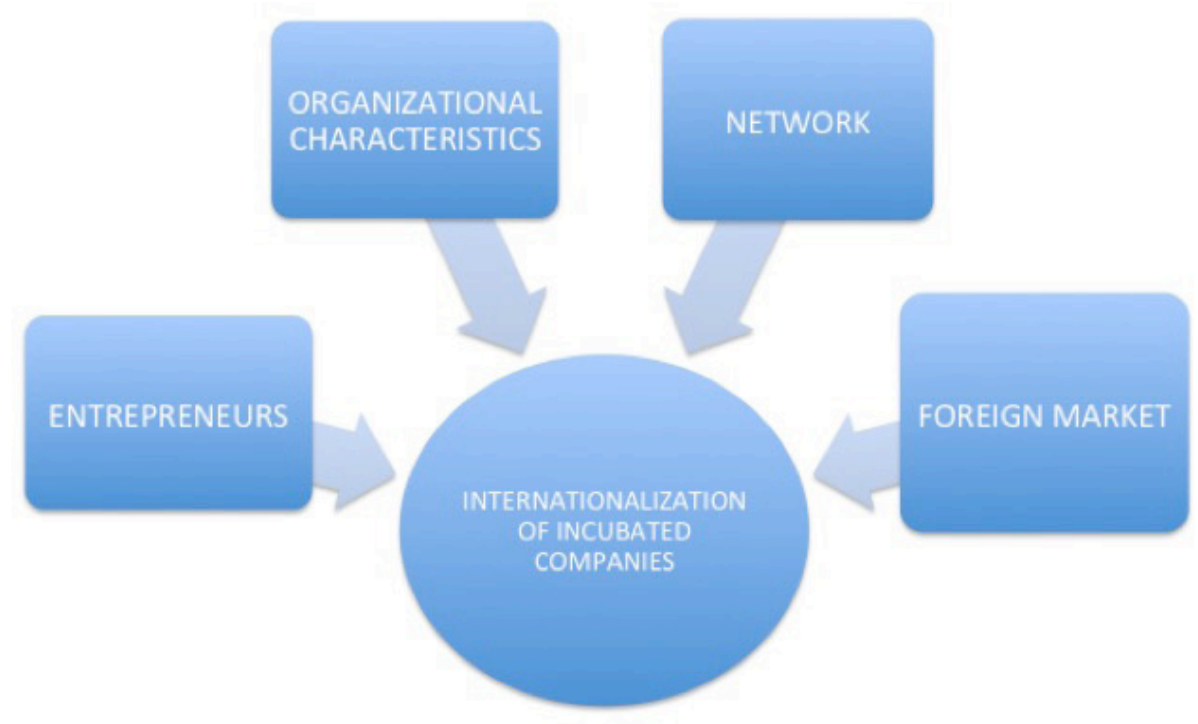

Figure I - Framework of Influence of Incubators towards the Internationalization of Incubated Companies 


\begin{tabular}{|c|c|c|}
\hline Constructs & Factors & Actions and service of the incubators \\
\hline Entrepreneurs & International Experience & $\begin{array}{l}\text { Provide the opportunity for entrepreneurs to gain international experience through exchanges and } \\
\text { international programs. }\end{array}$ \\
\hline $\begin{array}{l}\text { Organizational Charac- } \\
\text { teristics }\end{array}$ & $\begin{array}{l}\text { International motivation } \\
\text { Innovative products and services } \\
\text { Emphasis on innovation } \\
\text { Emphasis on marketing } \\
\text { Emphasis on quality } \\
\text { Emphasis on distribution } \\
\text { International strategies }\end{array}$ & $\begin{array}{l}\text { Provide an environment within the incubator that encourages an export culture and international- } \\
\text { ization. } \\
\text { Provide consultancy/advice/services on intellectual and industrial property. } \\
\text { Provide courses, training and tutorials in order to develop the company's capabilities in technology } \\
\text { management and innovation. } \\
\text { Provide courses, training and tutorials in order to develop the company's capabilities in marketing } \\
\text { management. } \\
\text { Provide courses, training and tutorials in order to develop the company's capabilities in quality } \\
\text { management. } \\
\text { Provide courses, training and tutorials in order to develop the company's capabilities in distribution } \\
\text { management. } \\
\text { Have members of the incubator team, advisers and consultants with international experience to } \\
\text { assist in the formulation of international strategies. } \\
\text { Provide the incubated companies with the opportunity to develop e-business and aspects related to } \\
\text { information and communication technology. } \\
\text { Provide access to financial and government institutions, export funding, foreign capital and venture } \\
\text { capital. }\end{array}$ \\
\hline Foreign Market & $\begin{array}{l}\text { Characteristics of the global envi- } \\
\text { ronment } \\
\text { Characteristic of the specific market }\end{array}$ & $\begin{array}{l}\text { Provides courses, tutorials and training for the development of knowledge about the foreign mar- } \\
\text { ket. } \\
\text { Provides access to company information on the foreign market through research and databases. } \\
\text { Provides access to consultancy / advisory / services import and export. } \\
\text { Provides access to consultancy / advisory / services of international technology transfer. } \\
\text { Provides dissemination of projects and products of the incubated companies abroad. } \\
\text { Provides identification and business prospects and partners in foreign markets. }\end{array}$ \\
\hline
\end{tabular}

Figure 2 - Constructs and Factors Associated with the Actions and Services that Contribute towards the Internationalization of the Incubated Companies 


\section{Method}

This paper presents a descriptive cross-sectional study, in which data collection occurred in a single instance. According to Hair et al. (2005), a descriptive research is so named because it uses descriptive statistics, including frequency counts (quantity), measures of central tendency or a measure of variation, such as the standard deviation, to characterize a sample or population. This type of research, also known as a survey, is an essentially quantitative in nature. Thus, it is characterized by frequency response data, presented in table form, fulfilling the goal of generalizing sample results to the target population (Malhotra, 200I). The remaining study procedures are described below.

\section{Sample selection}

The universe of this research consists of the total of firms in technology incubators in Brazil. Thus, we identified 635 firms if technology incubators in Brazil, which constitute the study population. Incubators were identified from Internet searches in the network of local incubators and regional, in websites of incubators, science and technology parks as well as other web sites related to the topic in question.

The interviews were conducted by telephone with the manager of each company, with the aid of a specialized team to collect data, properly supervised by the investigators. Of these 638 incubators, II5 responded to the questionnaire, a total of $18 \%$. As the participation was spontaneous, the representativeness of the sample cannot be assured, especially considering that many contacts were made in December 2012 to February 2013, the holiday season in Brazil.

\section{Data collection and analysis procedures}

A questionnaire was used to obtain information, as this makes data collection more concise and allows for standardization in the collection process, facilitating their quantitative analysis. The instrument was tested during November 2012, with three companies. Before applying the questionnaire three filter questions were used to ensure that the incubator met the selection criteria. No questionnaires had to be discarded.

The presentation of the results of the survey included descriptive analysis of the variables that comprised the evaluation blocks, based on the proposed analysis model. For the questions relating to actions and services of incubators that contribute to the internationalization of the incubated companies, descriptive statistics with the frequency data were used.
According to Malhotra (200I) the objective of the frequency distribution is to obtain a count of the number of responses associated with the different values for the variable, which provides the basic information, which can be summarized with the aid of descriptive statistics. A set of statistical tests was also used to assess the relationship between the variables, based on the intersection tests, and the differences in perceptions between the respondents of the sample, based on the non-parametric test. This univariate statistical technique was used to determine whether the samples from different groups arise from populations with equal means, based on a single dependent variable metric. The considered margin of error was $5 \%$.

\section{Results and Discussion}

The sample includes II 5 incubated companies, which $19.1 \%$ are located in São Paulo, $14.8 \%$ in Porto Alegre and 12.2\% in Rio de Janeiro. $46.1 \%$ of companies are located in these three cities. In the same way, $67 \%$ of incubators are located in the Southeast of Brazil, $31.3 \%$ in the South region and only $1.7 \%$ in the Northeast and Midwest jointly. Due to concentrate Brazilian developing in South and Southeast regions, the incubators also are predominantly located in these regions.

In average, the companies have 4 employees. $76.7 \%$ were founded after 2008 and $30.5 \%$ of companies have less than two years of existence. These characteristics are consistent with the profile of incubated companies in general (Anprotec, 2005).

Regarding to process of incubation, $63.5 \%$ of companies entered to the incubator after 2010 and $24.5 \%$ has less than one year in the incubator. $34.8 \%$ of companies are in public incubators, $31.3 \%$ for non-profit institutions and $30.4 \%$ for-profit organizations. The majority, $73.9 \%$ of the incubators, has some type of relationship with university or research center. The interviews indicated that $39.1 \%$ of incubators are located in public universities and $27.8 \%$ are in private universities. This result confirms that the Brazilian incubation process is strongly connect to universities and research centers.

Among the four constructs (Table I), the results indicate that the Organizational Characteristics of Incubated is the most important to support the internationalization process (2.83). This result is consistent with that found by Engelman \& Fracasso $(2013)$ in which $42 \%$ of the incubator managers this construct considered more important. 
The second construct is Network (2.69), follow by Entrepreneurs (2.29). At last, the Foreign Market (2.13). Unlike, in the results found by Engelman \& Fracasso (20I3) with incubated and graduated companies, the Foreign Market was the second construct, follow by Network. This difference in perception between managers of companies and managers of incubators may indicate that incubated as still being structured, prioritized characteristics still more general than those specifically aimed at internationalization.

\begin{tabular}{|l|l|l|}
\hline Constructs & Mean & $\mathrm{N}$ \\
\hline Entrepreneurs & 2,29 & $\mathrm{II}$ \\
\hline $\begin{array}{l}\text { Organizational Character- } \\
\text { istics }\end{array}$ & 2,83 & $\mathrm{II}$ \\
\hline Network & 2,69 & $\mathrm{II}$ \\
\hline Foreign Market & 2,13 & $\mathrm{II}$ \\
\hline
\end{tabular}

Table I - The Constructs that influence the internationalization process

The data shows that $30.5 \%$ of companies in the sample have less than two years of existence. At the beginning of operations, the companies consider support of incubator of great importance to internationalization. For them, the incubator should support the company to develop their capabilities before to planning to internationalization. The second, the incubated companies stress the importance of incubator help to develop national and international network.

The data shows that half of the surveyed actions and services are provided with medium or high intensity by the incubators. The actions and services available with more intensity by the incubators are: consultancy / advice / services on intellectual and industrial property (3.76); courses, training and tutorials in order to develop the company's capabilities in technology management and innovation (3.42) and related strengthening of national networks, such as strengthening and expansion of national business relationship networks (3.50) and opportunity to participate in national trade fairs events (3.40).

The actions and services available with less intensity by the incubators are: attract foreign incubated ventures (I.62), identification and business prospects and partners in foreign markets (1.97), dissemination of projects and products of the incubated companies abroad (1.99). This result shows that the actions of the incubators geared to international business are incipient.

\section{International Operations}

In the sample, we identified 13 incubated companies with international operations. Regarding to time of internationalization, 9 companies started the process less than two years ago, 2 companies are in international market for three years and two for more than 5 years.

The results demonstrate that incubation positively affects the internationalization of companies, since approximately $8 \%$ of the incubated companies began the process of internationalization. This index can be considered high compared to less than $2 \%$ of micro and small exporters in Brazil. If we consider that only a small share of exports is of Brazilian medium and high technology (MDIC, 2010; Sebrae, $20 \mathrm{II}$ ), this figure is even higher.

The modes of entry into foreign markets used by incubated companies are exporting and strategic alliance. This result is consistent with that found by Engelman and Fracasso (2013). These companies sell their products and services predominantly to Western Europe and South America. According to Figure 3, the export intensity has a concentration in three groups: 8 companies export less than $5 \%$ of total sales, 3 companies export $30 \%$ to $40 \%$ and 2 have strong focus on international market (more than $81 \%$ of sales).

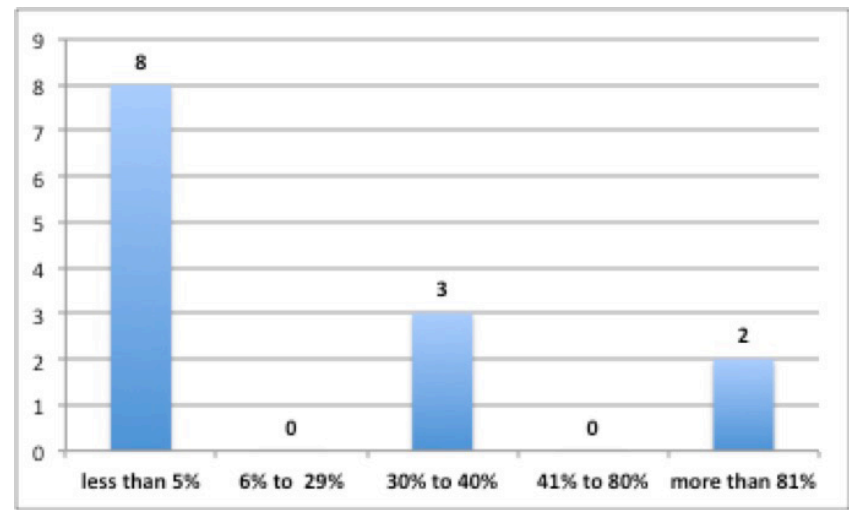

Figure 3 - Export Intensity of Incubated Companies 
Comparing the importance of each construct to internationalization process (Table 2), we can observe a difference between domestic and international companies, but the ranking of importance is the same: Organizational Characteristics, Network, Entrepreneurs and Foreign Market. The Mann-Whitney $U$ test indicated no statistically significant differences in the importance attributed by respondents.

This result indicates that managers of incubated companies operating in the domestic and foreign markets have the same perception regarding to the services and actions of incubator to foster the internationalization process.

\section{Incubators and Internationalization Program}

According to managers, it was found that $28.7 \%$ (33) of the incubators have formal program focused on the internationalization of companies incubated, and $71.3 \%$ (82) do not yet have. The mean of each construct is higher in the companies located in incubators with internationalization program (Table 3).

Then, firms located in incubators with internationalization program perceive differently the services and actions of incubator to foster internationalization process. The Mann-Whitney $U$ test indicated that the difference is significant in all four constructs: Entrepreneurs (.000), Organizational Characteristics (.026), Network (.024) and Foreign Market (.000).

\begin{tabular}{|l|l|l|l|l|}
\hline & Domestic & Inaternational & & \\
\hline Constructs & Mean & $\mathrm{N}$ & Mean & $\mathrm{N}$ \\
\hline Entrepreneurs & 2,22 & 102 & 2,85 & 13 \\
\hline Organizational Characteristics & 2,82 & 102 & 2,97 & 13 \\
\hline Network & 2,66 & 102 & 2,95 & 13 \\
\hline Foreign Market & 2,13 & 102 & 2,18 & 13 \\
\hline
\end{tabular}

Table 2 - The constructs of influence of incubation process in domestic and international companies

\begin{tabular}{|l|l|l|l|l|}
\hline & $\begin{array}{l}\text { Internationalization } \\
\text { Program }\end{array}$ & $\begin{array}{l}\text { Without } \\
\text { Internationalization } \\
\text { Program }\end{array}$ & ( & \\
\hline Constructs & Mean & $\mathrm{N}$ & Mean & $\mathrm{N}$ \\
\hline Entrepreneurs & 2,94 & 33 & 2,02 & 82 \\
\hline Organizational Characteristics & 3,10 & 33 & 2,72 & 82 \\
\hline Network & 2,98 & 33 & 2,58 & 82 \\
\hline Foreign Market & 2,64 & 33 & 1,94 & 82 \\
\hline
\end{tabular}

Table 3 - The constructs of influence of incubation process in companies located in incubators with internationalization program versus incubators without internationalization program

\begin{tabular}{|l|l|l|l|l|}
\hline & $\begin{array}{l}\text { International } \\
\text { Experience }\end{array}$ & $\begin{array}{l}\text { Without } \\
\text { International Experience }\end{array}$ & & \\
\hline Constructs & Mean & $\mathbf{N}$ & Mean & $\mathbf{N}$ \\
\hline Entrepreneurs & 2,01 & 76 & 2,82 & 39 \\
\hline Organizational Characteristics & 2,66 & 76 & 3,17 & 39 \\
\hline Network & 2,51 & 76 & 3,06 & 39 \\
\hline Foreign Market & 1,99 & 76 & 2,42 & 39 \\
\hline
\end{tabular}

Table 4 - The constructs of influence of incubation process in incubated companies with managers with international experience versus managers without international experience

ISSN: 07 I8-2724. (http://www.jotmi.org)

Journal of Technology Management \& Innovation (c) Universidad Alberto Hurtado, Facultad de Economía y Negocios. 


\section{Managers and International Experience}

Regarding to manager's companies, they are 35 years old, in average. The sample is composed predominantly of men (80\%) with high education level: post-graduate $(53.1 \%)$ and graduate $(32.2 \%) .76 \%$ of the respondents reported having no international experience and $34 \%$ have some international experience.

The results indicated that managers with international experience perceive differently the services and actions of incubator to foster internationalization process. The Mann-Whitney $U$ test indicated that the difference is significant in all four constructs: Entrepreneurs (.00I), Organizational Characteristics (.00I), Network (.00I) and Foreign Market (.02I).

\section{Conclusion}

The analytical model includes the factors influencing the internationalization of enterprises, especially micro and small technology-based companies, and aspects of the incubation process of technological enterprises, as well as the activities and services provided by incubators. To meet the objective of the study, a survey was conducted among companies located in Brazilian incubators.

The proposed model proved useful in identifying the actions and services of the incubators that contribute to the internationalization of enterprises. The division into categories was important, both for operational data collection, and to provide better visualization of the theory and the points where incubators can play a more effective role in the internationalization of enterprises.

The results demonstrate that incubation positively affects the internationalization of companies and indicate the actions and services that contribute towards the internationalization of incubated companies. The survey shows actions and services are provided by the incubators and also reveals aspects that could be improved in order to expand the internationalization of incubated companies.

Compared to Engelman and Fracasso (2013), one can see that the actions and services provided by incubators present greater results after the incubation period, when they are graduated. This finding is consistent with the different time when companies are, since most of the companies incubated focuses initially stabilize the domestic market, whereas companies graduated, already organized internally, are better able to compete in foreign markets. In both cases, the actions of the incubators contribute to the internationalization of firms, providing greater chances of success in the external market, even if it is just take the next stage incubation.
These services and actions identified in this study may help in the definition of strategies as to what can be provided to new firms, encouraging their entry into international markets. They also serve as a recommendation for technology incubators and government programs that aim at contributing to the internationalization of incubated and graduated enterprises.

\section{References}

AERTS, K., Matthyssens, P.,Vandenbemp, K. (2007). Critical role and screening practices of European business incubator. Technovation, 27 (5), 254-267. http://dx.doi.org//0.10/6/j. technovation.2006.12.002

ANDERSEN, O., Buvik, A. (2002). Firms' Internationalization and Alternative Approaches to the International Customer/ Market Selection. International Business Review, II (3), 347363. http://dx.doi.org/I0.10I6/s0969-593 I(0I)00064-6

ANDERSSON, S. (2000). The Internationalization of the firm from an entrepreneurial perspective. International Studies of Management \& Organization, 30 (I), 63-92.

ANPROTEC (2005). Panorama 2005. Retreived October 02, 2012, from http://www.anprotec.org.br .

APEX BRASIL (2009).Apex-Brasil e Anprotec firmam acordo de $R \$ 6$ milhões. Retreived April I0, 20I2, from http://www. apexbrasil.com.br/.

BAETA, M. C., Borges, C. V., Tremblay, D. G. (2006). Empreendedorismo nas incubadoras: Reflexões sobre tendências atuais. Comportamento Organizacional e Gestão, 2 (I), 7-18.

BILKEY, J., Tesar, G. (1977). The export behavior of smaller Wisconsin manufacturing firms. Journal of International Business Studies, 9 (I), 93-98. http://dx.doi.org//0.1057/ palgrave.jibs.8490783

CAVUSGIL, S. (1980). On the Internationalization Process of Firms. European Research, 8 (I), 273-28I.

COVIELLO, N., Munro, H. (1997). Network relationships and the internationalization process of small software firms. International Business Review, 6 (4), 36I-386. http://dx.doi. org/10.1016/s0969-5931(97)00010-3

CZINKOTA, M. (1982). Export Development Strategies: US Promotion Policies. Praeger Publishers, New York. 
ECABIT (2008). Regional and global networking of business incubators. Retreived November 10, 2012, from http://www. ecabit.org/ .

ENGELMAN, R., Fracasso, E. M. (20/3). Contribuição das incubadoras tecnológicas na internacionalização das empresas incubadas. Revista de Administração da Universidade de São Paulo - RAUSP, 48 (I), I65-178. http:// dx.doi.org/ / 0.5700/rausp I 080

HAIR, J. F., Jr. et al. (2005). Fundamentos de métodos de pesquisa em administração. Bookman, Porto Alegre.

HILAL, A., Hemais, C. A. (2003). O Processo de Internacionalização na Ótica da Escola Nórdica: Evidências Empíricas em Empresas Brasileiras. Revista de Administração Contemporânea, 7 (I). http://dx.doi.org//0.1590/s/4I565552003000100006

IDISC (2008). Incubator Toolkit. Retreived November 10, 2012, from http://www.idisc.net/en/Toolkit.html\#.

JOHANSON, J., Vahlne, J. (1977). The internationalization process of the firm: a model of knowledge and increasing foreign market commitment. Journal of International Business Studies, 8 (I), 23-32. http://dx.doi.org//0.1057/ palgrave.jibs. 8490676

JOHANSON, J., Vahlne, J. (2003). Business relationship learning and commitment in the internationalization process. Journal of International Entrepreneurship, I (I), 83-I0I.

JOHNSON, J. E. (2004). Factors Influencing the Early Internationalization of High Technology Start-ups: US and UK Evidence. Journal of International Entrepreneurship, 2 (I/2), 139-154. http://dx.doi.org//0.1023/ b:jien.0000026910.87323.4e

JONES, M.V. (1999). The internationalization of small hightechnology firms. Journal of International Marketing, 7 (4), $|5-4|$.

MADSEN, T. K., Servais, P. (1997). The internationalization of born globals: an evolutionary process? International Business Review, 6 (6), 56I-583. http://dx.doi.org/10.1016/ s0969-593I (97)00032-2

MALHOTRA, N. (200I). Pesquisa de marketing: uma orientação aplicada. 3a. Edição. Bookman, Porto Alegre.

MCDOUGALL, P. P., Oviatt, B. M., SHRADER, R. C. (2003). $A$ comparison of international and domestic new ventures. Journal of International Entrepreneurship, I (I), 58-82.
MDIC - Ministério do Desenvolvimento, Indústria e Comércio Exterior (2010). Exportação brasileira por porte de empresa. Secex, Brasília.

OVIATT, B. M., McDougall, P. P. (1994). Toward a theory of international new ventures, Journal of International Business Studies, 25(I), 45-64. http://dx.doi.org//0.1057/palgrave. jibs.8490193

REID, S. D. (I98I).The decision-maker and export entry and expansion. Journal of International Business Studies, 12 (2), I0I - I I2. http://dx.doi.org/ I0. I057/palgrave.jibs.849058 I

RENNIE, M.W. (1993). Global Competitiveness: Born Global. McKinsey Quarterly, 4 (I), 45-52.

ROCHA, A. D. et al. (2005). Processo de Internacionalização de Empresas Nascidas Globais: Estudo de Casos no Setor de Software. Enanpad XXIX.Anpad, Brasília.

SEBRAE - Serviço Brasileiro de Apoio às Micro e Pequenas Empresas (20lI). As micro e pequenas empresas na exportação brasileira 1998-20 I0. Sebrae, Brasília.

SHARMA, D. D., Blomstermo, A. (2003) The internationalization process of born globals: a network view. International Business Review, 12 (6), 739-753. http://dx.doi. org//0.1016/j.ibusrev.2003.05.002

SOFTEX (2008). Sociedade para Promoção da Excelência do Software Brasileiro. Retreived November 10, 2012, from http://www.softex.br.

STAINSACK, C. (2003). Estruturação, Organização e Gestão de Incubadoras Tecnológicas. Unpublished master dissertation. Curitiba: Centro Federal de Educação Tecnológica do Paraná, 2003.

STYLES, C., Seymour, R. G. (2006). Opportunities for marketing researchers in international entrepreneurship. International Marketing Review, 23 (2), 126-145. http:// dx.doi.org/I0.I | 08/0265 |3306/0660056 